\title{
An Emerging Theory to Guide Clinical Social Workers Seeking Change in Regulation of Clinical Social Work
}

\author{
Dianna Cooper-Bolinskey
}

\begin{abstract}
U.S. regulation of social work began in the 1940s. By the mid-1990s, all jurisdictions within the United States regulated the profession through licensure. One purpose of licensure is to protect the public and the profession; however, legislation defining social work varies vastly among jurisdictions. The variation exists not only between jurisdictions, but also within licensure categories. The disparity within clinical social work continues without resolve. This qualitative study explored the barriers encountered and solutions used in three states as they secured laws allowing licensed clinical social workers to independently provide mental health services. Grounded theory research, based on information from 12 historians, is used to develop a theory to aid advocates in jurisdictions not yet achieving fully independent practice of clinical social work. The emerging theory offers a complex-systems approach to using a strategic framework to overcome barriers when attempting policy change. The primary purpose of the research is to develop strategies that aid in securing changes in clinical social work regulation. The emerging theory may serve a broader purpose by supporting the Association of Social Work Board's (ASWB) goal of practice mobility and license portability. As advocates in various jurisdictions attempt to align regulations with the Model Social Work Practice Act from ASWB, they may experience barriers. This emerging theory could guide efforts to change clinical social work regulation.
\end{abstract}

Keywords: Advocacy; barriers to change; changing legislation; clinical social work; grounded theory; jurisdictional regulation

Regulation of social work began in the 1940s (Bibus \& Boutte-Queen, 2011) and by 1992, every state within the United States regulated the profession within some categories of licensure (Randall \& DeAngelis, 2013). The purpose of licensure involves protection of both the public and the profession (Association of Social Work Board [ASWB], 2016; Bibus \& Boutte-Queen, 2011; Biggerstaff, 1995; Council on Social Work Education [CSWE], 2018; Groshong, 2009; Marks \& Knox, 2015). Essentially, licensure regulations establish that licensed social workers meet specific standards to practice, are monitored by a regulatory board, and practice within the guidelines specified in state statutes (Bibus \& Boutte-Queen, 2011; Biggerstaff, 1995; CSWE, 2018).

While there are many benefits of professional regulation by licensure, one problematic inconsistency is the variation among jurisdictions with differing scopes and categories of practice (Collins, Coleman, \& Miller, 2002; Mark \& Knox, 2015). This is especially true in the specialization of clinical social work (Groshong, 2009). Nurses and physicians are examples of professionals who are regulated by licensure and are perceived as having little variation in practice standards from one jurisdiction to another; in other words, providers and patients share some common ideas about the functions of a registered nurse $(\mathrm{RN})$ or a

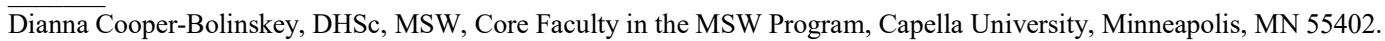


family practice physician (FPP) regardless of where services are provided (CooperBolinskey, 2017).

However, social work has significant variations in regulations across the United States, leaving some question about the fulfillment of the purpose of licensure. Marks and Knox (2015) stated, “...though much progress has been made, there are many issues left to be resolved regarding professional regulation, including the balance of public protection, professional competence and practice, and addressing the need for consistency and continuity on a national and international scale" (p. 170). Groshong (2009) stated, "There has been confusion between generalist social work practice and clinical social work practice which needs to be identified; there are differences that need to be accepted, and there are conflicts between the two groups that need to be resolved" (p. 16). Regulation of licensed clinical social work is the primary interest underlying the research at hand. The purpose of the study is to help clinical social workers develop a useful understanding of the barriers encountered and solutions used to overcome obstacles when attempting to change policies that define the scope of practice. The results of the study can be used to advocate for changes in laws regulating clinical social work.

\section{Background}

In order for the rationale for the study to be best relayed to readers, some historical context about the social work profession is important. Additionally, it may be helpful to have a common understanding of social work practice and how the profession is regulated. The focus of the study remains on clinical social work, though it is important to understand clinical social work in the context of the broader scope of social work practice.

\section{A Brief Historical Summary}

Social work originated with volunteer efforts to care and advocate for abandoned children, people in poverty, and those who were otherwise disadvantaged in the late 19th century in Europe and North America (Stuart, 2013). Social work evolved from volunteering and friendly visiting to an apprentice-based occupation in the early 20th century; this served as the springboard for later development of clinical social work (Groshong, 2009). The 1930 Census classified social work as a profession for the first time (Stuart, 2013). Social workers initially focused on the issue of poverty but quickly expanded efforts to serve children and families in other ways (Stuart, 2013).

In the 1930s, the profession began to be recognized as a service profession as a result of the growth of professional organizations, educational programs, and publications (Dyeson, 2004; Stuart, 2013). Shortly after, the Great Depression and World War II demanded social workers expand their focus to include mental health concerns (Groshong, 2009, McNutt 2013). According to McNutt (2013), until the end of the 1950s, social work was a united profession with a rather clear, singular focus. The 1960s split attention of the profession between poverty (and programs to serve those in poverty) and mental health needs; this became a time of political activism (Stuart, 2013) and brought disagreements within the profession as to its future direction (McNutt, 2013). The profession continued to evolve with expanded use of multidimensional approaches and theories with intentional 
inclusion of mental healthcare, such as task-centered treatment, cognitive behavioral approaches, and reality therapy (Groshong, 2009; McNutt, 2013).

Though initial efforts for licensure began in the 1940s, the 1980s brought lobbying efforts for regulation of the profession together and many states were able to achieve professional regulation (Bibus \& Boutte-Queen, 2011; Groshong, 2009). This time also highlighted the professional shift to include macro-micro divisions and the creation of generalist social work; it is essentially when multiple categories of social work practice emerged (McNutt, 2013). By the 21st century, some levels of social work were regulated in all 50 states (Clark, 2013; Dyeson, 2004; Stuart, 2013). Licensing also facilitated the growth of private practice as many jurisdictions provided the standards for independent practice (Stuart, 2013).

In 2018, the Association of Social Work Boards (ASWB) reported that bachelor of social work (BSW) practice was regulated in 42 jurisdictions, master of social work (MSW) practice was regulated in 48 jurisdictions, independent advanced generalist practice was regulated in 16 jurisdictions and clinical social work practice was regulated in 54 jurisdictions (ASWB, 2018b). Jurisdictions include each of the states, districts, and commonwealths within the United States as well as the territories of Guam, Puerto Rico, Virgin Islands, Northern Mariana Islands, and American Samoa (ASWB, 2018b). On September 28, 2018, ASWB reported there were 480,026 licensed social workers in the United States (ASWB, 2018c), down from 495,130 in 2015 (ASWB, 2015a).

\section{Understanding Divisions of Scope of Practice}

Various groups of social workers chose multiple, different directions for professional practice; this expansion of focus for the profession created both positive and negative points of view about the profession. Epple (2007) explained how some criticized the profession for abandoning its initial roots in advocacy for marginalized groups/populations and saw the added focus of mental health practice as confusing, unclear, and unnecessary. Others applauded the profession for adding mental health advocacy and services not seen before for individuals and families (Epple, 2007). Some of the aforementioned debate continues even today, though many social workers agree with the expansion of foci within the profession and recognize the advantages the expansion created (Cooper-Bolinskey, 2017). Weismiller and Whitaker (2013) identify the themes of change in the profession as movement from public-agency auspices to private, nonprofit auspices; increasing numbers of social workers in private practice; and increasing identification of behavioral health and mental health as an area of practice specialization.

\section{Social Workers as Mental Health Providers}

According to the National Provider Identifier (NPI) registry, as of December 11, 2018, there are 996,266 licensed primary mental health providers in the United States (U.S. Centers for Medicare and Medicaid Services, 2018). The NPI Registry composition by provider type indicates the following providers: Psychiatrists and Neurologists, 62,094 (6.2\%); Physician Assistants and Clinical Nurse Specialists, 2,287 $(<1 \%)$; Psychologists, 175,021 (17.6\%); Clinical Social Workers, 266,779 (26.8\%); Counselors, 419,818 (42.1\%); Marriage and Family Therapists, 58,437 (5.9\%); and Other mental health 
providers (social workers and nurses), 11,830 (1.2\%; U.S. Centers for Medicare and Medicaid Services, 2018).

The National Association of Social Workers (NASW) reported $60 \%$ of mental health professionals are clinically trained social workers, compared to $23 \%$ of psychologists, $10 \%$ of psychiatrists, and 5\% of psychiatric nurses (NASW, 2016). Groshong (2009) reported that $96 \%$ of licensed social workers were providing direct services; the rate of actionable complaints against licensed clinical social workers was about $4 \%$ over the past 10 years. Licensed clinical social workers are providing most of the mental health services in the country with few complaints by those receiving their services. Certainly, licensed clinical social workers are well positioned to provide the much-needed mental health services needed within the United States (Groshong, 2009).

\section{Examples of Current Regulatory Issues}

In 2017, when this study was being conducted, the researcher learned from interviewees that 10 jurisdictions did not allow licensed clinical social workers to diagnose mental health disorders. Some states had vague statements outlined in their rules, and yet in other states licensed clinical social workers used diagnostic impressions to then provide and bill for mental health services. Similarly, seven jurisdictions did not allow licensed clinical social workers to practice psychotherapy. Yet, in some jurisdictions, services were provided using other but similar methods. These two inconsistent and practice-limiting issues for licensed clinical social workers are examples of the need for policy change (Groshong, 2009). Policy change provides consistency and supports ASWB's initiative to support practice mobility and license portability. The study was initially designed without any consideration of ASWB's initiatives; however, given the emergence of the initiatives and their value to the profession, it seems worthwhile to recognize how the study may support the initiatives. When policies are more consistent, practice mobility and license portability are more easily attainable.

\section{ASWB Initiatives}

ASWB (2017) recognizes there are some problems associated with the current state of licensure; a few of the issues include lack of consistency in social work services across jurisdictions, confusion about the profession by clients and constituents, and the issues with mobility of social workers (the lack of reciprocity or transferability of licenses when social workers move among the jurisdictions). ASWB's Model Social Work Practice Act serves as one method of addressing these issues (ASWB, 2015b). The Practice Act defines recommended standards and scopes of practice for the profession within four categories of practice (bachelor, master, advanced generalist, and clinical). The Association maintains the document, via regular updates by strategically created committees, in an attempt to establish common standards in social work practice among the various jurisdictions while assuring protection of the public (ASWB, 2015b). The Clinical Social Work Association posits that the practice of clinical social work needs more clear and specific definitions that align across jurisdictions (Groshong, 2009).

In 2016, ASWB began another initiative, Social Work Practice Mobility and License Portability, to further address these concerns. The Association created a website (ASWB, 
2019) to offer easily accessible information and resources (ASWB, 2017). One component of the initiative focuses on more similarities, fewer differences, which includes commonalities of education, examination, and experience. While the effort remains a work-in-progress, ASWB professes dedication to this effort to achieve professional mobility and portability (ASWB, 2017).

This initiative is significant for many reasons. ASWB's initiative is supported by leadership from the National Association of Social Workers (NASW) and the Council on Social Work Education (CSWE), among others. The collaboration between ASWB, NASW, and CSWE presents a cohesive and united effort by multiple national professional social work organizations not seen in the past. Secondly, the emphasis on social work as a healthcare profession highlights the need for nationally consistent definitions and services; this improves understanding of the profession. Additionally, the consistency aligns much more closely with the purpose of licensure to protect the public and the profession (CooperBolinskey, 2017).

A glaring issue that remains a concern with achieving mobility and portability is the need for changing policies in some jurisdictions to better align with the Model Social Work Practice Act (ASWB, 2015b). In addition to the need to modify social work licensure policies, clinical social work regulation also needs to be modified in some jurisdictions as well (Groshong, 2009). This study is timely because it produces a useful tool to aid social workers in their efforts to change licensing laws.

\section{Summary}

There continues to be no national licensure regulating professional practice; each jurisdiction regulates its own professional practice (CSWE, 2018; Randall \& DeAngelis, 2013). Social work remains a relatively young profession, providing a variety of different services and using a variety of different service mechanisms. As such, licensure laws continue to vary, with some differences impacting scope of practice (Cooper-Bolinskey, 2017).

This study began with the researcher's interest in understanding the variations in regulation of clinical social work. Within this area of social work practice alone, there remain jurisdictional differences that impact scope of practice (Groshong, 2009). For example, some (but not all) jurisdictions allow for licensed clinical social workers to provide services in private practice, some jurisdictions allow licensed clinical social workers to diagnose mental health disorders, and some jurisdictions allow licensed clinical social workers to bill for services under their own license as opposed to billing under a supervising provider (Cooper-Bolinskey \& Blower, 2016). These variations create confusion for clients, other providers, and even among social workers.

In exploring the variations in scope of clinical social work practice, it became obvious there was little information available through a literature review. This remains a seriously under-researched topic. Furthermore, regulations are difficult to access, read and interpret. ASWB recently added to their website a database of regulations, allowing for comparison using search tools (ASWB, 2018a). However, the broader context, or landscape, of scope of clinical social work practice within the United States is still difficult to access and 
understand. With extensive time spent further exploring the literature, reviewing websites, consulting with association representatives, and speaking with national advocates, the researcher developed a better level of understanding of these issues which became the basis for executing the study.

\section{Need for the Study}

The researcher's interest in jurisdictional differences within the scope of practice for social workers was confirmed through the literature review. Social work regulation is not consistent nationally as some states do not regulate the various categories of social work practice. Social work licenses have as many as 56 different titles across the various jurisdictions (CSWE, 2018). The scope of practice across jurisdictions is quite inconsistent with some not allowing social workers to perform the same types of practice, although the educational requirements and qualifying exams are consistent (ASWB, 2015b). While these examples are important, they represent only a sprinkling of the differences in social work regulations across jurisdictions. In order for the profession to have a reasonable platform to establish portability and mobility of licensure, there need to be effective strategies to use in changing licensing policy (Cooper-Bolinskey, 2017). Results from this study may be useful to clinical social workers seeking to make changes through the policy process.

\section{Methods}

This qualitative, inductive systems study utilized the Corbin and Strauss (2015) model of grounded theory, allowing a free-flowing, interpretive, and dynamic process to capture points that needed to be included in the analysis. Data were collected from historians (i.e. study participants) through recorded and transcribed semi-structured interviews and provided documents. Each historian was provided a copy of their transcribed interview to make corrections, comments, or simply accept without correction. Each collection of data was analyzed individually, reviewed and coded, then added to the collective data set. With each addition of data, the most current data set was also analyzed. Core categories and linking categories were noted as they emerged. Data were collected until the data demonstrated saturation or until there were no more available and willing participants. Corbin and Strauss (2015) discussed the value of using computer assisted analysis in qualitative research, thus, NVivo 11 Pro was used in data analysis (NVivo, 2017) along with note taking. Summaries of each interview were written throughout the data collection process, analyzed independently, added to the collective data set and then analyzed at each addition of data until completion of all participant data collection. Once the collection of themes related to barriers and solutions was complete, the research team used restrictive coding to categorize the barrier and solutions themes. An outline of the framework to stage the emerging theory was then constructed in consultation with the project consultant. Following the Corbin and Strauss model of grounded theory, once the team reached consensus and a theory was developed, the formal writing of the study began.

Purposive sampling was used to assure selection of historians who had relevant knowledge on the topic and could provide differing perspectives. The three states of Florida, Minnesota, and Texas were selected as sample states for this study based on four 
criteria: change of their legislation in the last 30 years to allow licensed clinical social workers to provide private and independent mental health services; there was some degree of difficulty in changing social work related legislation; ASWB providing the name of at least one potential historian from the state; and variation in size, population, industry, political affiliation of the state, and type of regulatory board. The initial sample pool consisted of the individuals suggested by ASWB, each state's NASW Executive Director, and a member of each state's regulatory board. Additionally, snowball sampling was used to gather additional historians, as needed, until the data for each state was saturated or until no further historians were identified, whichever came first. Coincidentally, all available and willing contacts were utilized as historians and the comprehensive evaluation of the data reached saturation.

The collective group of 12 historians came from the three states of Florida, Minnesota, and Texas, though two were considered national historians with substantially more experience than within the identified states. Of the group, four were male and eight were female. One historian was a mid-career professional, eight were advanced career professionals, and three were retired. All of the historians had earned a master's degree, 10 of which were in social work, whereas two had earned master's degrees in other disciplines of study. Six of the historians had doctoral degrees in social work, social policy, or law. All of the historians were licensed social workers (two were licensed under the grandfathering clause). All of the historians had substantial experience working with statelevel legislation related to social work regulation. Every historian had at least 10 years of experience with legislative work and two historians had nearly 40 years of experience. Seven historians had more than 30 years of experience working with social work regulation.

Of the 12 historians, nine (Historians 1, 2, 3, 4, 5, 6, 8, 9, and 11) contributed a Barrier theme; three historians (Historians 7, 10, and 12) contributed content to support themes but did not define any new Barrier themes. Of the 12 historians, eight (Historians 1, 2, 3, 5, 6, 8, 9, and 11) contributed a Solution theme; four historians (Historians 4, 7, 10, and 11) contributed content to support themes but did not define any new Solution themes. Based on the analysis of the full data set, saturation was achieved in both Barrier and Solution themes.

While the study was able to reach its goal for number of historians, the researcher learned there was actually a quite small overall sample of possible historians for this type of study. Additional historians were identified in each state, and were contacted for possible inclusion as the referrals were received, but no additional historians agreed to participate. To that end, even though it was unclear whether saturation was achieved per state, the researcher was comfortable reporting saturation was achieved based on the full data set in both Barrier themes and Solution themes.

Codes were established to organize content from each historian interview into the following categories: Historian Credentials, State Information, Legislative Process, Barriers, Political Climate or Historic Events, Relationships among the Mental Health Professions, and Solutions. Comments, phrases, quotes, and relevant points were identified and coded into each of the noted categories. Summaries of the content from the interviews 
were written under each heading of Historian Credentials, State Information, Legislative Process, Political Climate or Historic Events, and Relationships among the Mental Health Professions. This arrangement helped to set the context for better understanding the Barriers and Solutions. These two categories of data were analyzed for themes then used in the development of the theory.

\section{Results}

Responses from all 12 historians were summarized into two analyses: one collective analysis of barrier themes and one collective analysis of solution themes used when working with legislation that regulates social work licensing.

\section{Barriers}

The historians were asked to identify barriers, or problems, experienced in their attempts to pass or change legislation that regulates clinical social work licensing. Historians described 21 barriers that were grouped, using restricted coding, into five categories to facilitate easier understanding and usage. Table 1 provides a summary of the groups of themes emerging from the interviews along with examples of supporting responses. Some responses are summarized for brevity while others are direct quotes.

Table 1. Barriers Experienced When Attempting Social Work Related Legislation

\begin{tabular}{|c|c|c|}
\hline Theme & Code & Supporting Responses \\
\hline \multirow[t]{5}{*}{$\begin{array}{l}\text { Political/ } \\
\text { Legislative }\end{array}$} & $\begin{array}{l}\text { The political climate } \\
{[\mathrm{H} 2]}\end{array}$ & $\begin{array}{l}\text { Texas is primarily administratively managed by Republicans. It is difficult to } \\
\text { get funds shifted from the criminal justice perspective to the healthcare focus. } \\
\text { [H1 (TX)] }\end{array}$ \\
\hline & $\begin{array}{l}\text { Legislative work takes } \\
\text { time [H2] }\end{array}$ & On average, it takes 3 sessions, 6 years, to get a bill passed. [H2 (TX)] \\
\hline & $\begin{array}{l}\text { Legislative sessions } \\
\text { move quickly [H2] }\end{array}$ & $\begin{array}{l}\text { Anything can happen when the laws are reviewed; while the legislature is in } \\
\text { session changes happen quickly. [H2 (TX)] }\end{array}$ \\
\hline & $\begin{array}{l}\text { Not valuing the need } \\
\text { for licensure [H1] }\end{array}$ & $\begin{array}{l}\text { Legislators ask from what the public needs to be protected. Another question } \\
\text { that kept coming up, "Can regulation be managed in a less expensive way"? } \\
\text { [H1 (TX)] }\end{array}$ \\
\hline & $\begin{array}{l}\text { Unpredictable } \\
\text { outcomes [H2] }\end{array}$ & $\begin{array}{l}\text { Anything can happen once the bill is open and in discussion/review. People } \\
\text { fear the risk of unwanted outcomes. [H2 (TX)] }\end{array}$ \\
\hline \multirow[t]{4}{*}{ Financial } & $\begin{array}{l}\text { Money [H2]-Financial } \\
\text { (State budgets) [H1] }\end{array}$ & $\begin{array}{l}\text { Republican leadership who will not spend money. The state maintains a large } \\
\text { "rainy day" fund. Getting money for any services is tough. Any bill with a } \\
\text { fiscal note attached will be difficult to pass in the legislature. [H1 (TX)] }\end{array}$ \\
\hline & $\begin{array}{l}\text { Money }[\mathrm{H} 2]-\text { Financial } \\
\text { (Association funding) } \\
{[\mathrm{H} 1]}\end{array}$ & $\begin{array}{l}\text { Overcoming problems with not just passing social work legislation, but the } \\
\text { right legislation, takes lobbying and outside help and associations often cannot } \\
\left.\text { afford the help. [H3 }(\mathrm{N})^{* *}\right]\end{array}$ \\
\hline & Logistics [H4] & $\begin{array}{l}\text { It can be challenging to coordinate meetings with the right people at critical } \\
\text { times. Clients with meaningful stories need to tell them to legislators, but } \\
\text { getting the meeting times coordinated, managing work and transportation for } \\
\text { the client, money to afford the travel, and even helping the client to maintain } \\
\text { motivation to speak with the legislators until meeting time takes substantial } \\
\text { time and commitment. [H4 (MN)] }\end{array}$ \\
\hline & $\begin{array}{l}\text { Medicaid is a broken } \\
\text { system [H1] }\end{array}$ & $\begin{array}{l}\text { Mental healthcare is somewhat lost in the Medicaid funding discussion. When } \\
\text { combined with stigma, getting funding for Medicaid is difficult. [H1 (TX)] }\end{array}$ \\
\hline
\end{tabular}




\begin{tabular}{|c|c|c|}
\hline Theme & Code & Supporting Responses \\
\hline \multirow[t]{5}{*}{$\begin{array}{l}\text { The } \\
\text { Profession }\end{array}$} & $\begin{array}{l}\text { Misunderstandings } \\
\text { about the social work } \\
\text { profession }[\mathrm{H} 1]^{*}\end{array}$ & $\begin{array}{l}\text { Social Workers are "pigeon holed" as child welfare workers. Few legislators } \\
\text { understand social work as a mental health profession. Getting clinical social } \\
\text { work provisions for mental health services was not intuitive when legislators } \\
\text { think of social workers as child welfare workers. [H1 (TX)] }\end{array}$ \\
\hline & $\begin{array}{l}\text { Nature of social work } \\
{[\mathrm{H} 1]}\end{array}$ & $\begin{array}{l}\text { People outside the profession devalue social work (i.e. social workers are } \\
\text { helpers and will do what they do anyway) regardless of if the proposal is } \\
\text { funded. Social workers join the profession as micro providers and often do not } \\
\text { see macro advocacy within their role. [H1 (TX)] }\end{array}$ \\
\hline & $\begin{array}{l}\text { Specializations in } \\
\text { social work [H5] }\end{array}$ & $\begin{array}{l}\text { Having specializations written into legislation has lost basic uniformity of the } \\
\text { profession nationally. State level specializations have produced more than } 60 \\
\text { titles of social workers in the U.S. which are not consistently used among the } \\
\text { states. [H5 (N)] }\end{array}$ \\
\hline & $\begin{array}{l}\text { Lack of a unified plan } \\
\text { for change [H3] }\end{array}$ & $\begin{array}{l}\text { Individuals or associations do not have the same goals for the law. } \\
\text { Associations do not differentiate between clinical and macro practice. [H3 (N)] }\end{array}$ \\
\hline & $\begin{array}{l}\text { Social work is a } \\
\text { primarily female } \\
\text { occupation [H9] }\end{array}$ & $\begin{array}{l}\text { Most of the legislators are male and don't think the same way as a female } \\
\text { driven profession. [H9 (TX)] }\end{array}$ \\
\hline \multirow[t]{3}{*}{ Educational } & $\begin{array}{l}\text { Initially, social workers } \\
\text { and legislators were not } \\
\text { informed about } \\
\text { certification or } \\
\text { licensure [H6] }\end{array}$ & They did not know what to do or how to start. [H6 (TX)] \\
\hline & $\begin{array}{l}\text { Educational Programs } \\
\text { need overhaul [H9] }\end{array}$ & $\begin{array}{l}\text { New social workers need a stronger understanding of the link between policy } \\
\text { making and professional practice. New social workers need to be better trained } \\
\text { in public speaking. [How does one testify meaningfully before the legislature if } \\
\text { they aren't well prepared in public speaking?] [H9 (TX)] }\end{array}$ \\
\hline & $\begin{array}{l}\text { Legislators having } \\
\text { misinformed } \\
\text { perspectives }[\mathrm{H} 2]\end{array}$ & $\begin{array}{l}\text { One legislator refused to support a bill because } 5 \text { constituents disagreed; he } \\
\text { based opinion on } 5 \text { constituents and didn't explore the perspective of the } \\
\text { whole. Governor and lieutenant governor sometimes sway legislators toward } \\
\text { their perspective and legislators do not challenge it. This is the "kiss of death" } \\
\text { for a bill. [H2 (TX)] }\end{array}$ \\
\hline \multirow[t]{4}{*}{$\begin{array}{l}\text { Miscellaneous } \\
\text { /Other }\end{array}$} & Media Influence [H2] & $\begin{array}{l}\text { Fake news and stigmas associated with political affiliation affect legislation. } \\
\text { Politicians are using twitter and limiting conversations on important issues to } \\
140 \text { characters. [H2 (TX)] }\end{array}$ \\
\hline & $\begin{array}{l}\text { Inadequately designed } \\
\text { legislative proposals } \\
\text { [H3] }\end{array}$ & $\begin{array}{l}\text { Scope of practice has to be well written and clear. Clinical social work } \\
\text { legislation has to address the ability to diagnose and the ability to perform } \\
\text { psychotherapy. Laws usually define the required exam, and some states do not } \\
\left.\text { clearly require the clinical exam. [H3 }\left(\mathrm{N}^{* *}\right)\right]\end{array}$ \\
\hline & $\begin{array}{l}\text { Influential opposition } \\
\text { [H6] }\end{array}$ & $\begin{array}{l}\text { Licensure related to social work practice was opposed by the nursing home } \\
\text { industry and the Department of Protective and Regulatory Services (because } \\
\text { they wanted status quo) and because they wanted to keep access to the Social } \\
\text { Work Associates as employees. The National Association of Black Social } \\
\text { Workers criticized licensing as a device for consolidating power and as } \\
\text { discriminatory. There were also some other associations that fought against } \\
\text { clinical licensure. [H6 (TX)] }\end{array}$ \\
\hline & $\begin{array}{l}\text { Opposition from } \\
\text { psychology (or other } \\
\text { mental health } \\
\text { providers)? [H3] }\end{array}$ & $\begin{array}{l}\text { Psychology is often the main objector when trying to design clinical social work } \\
\text { legislation. They fight against the right to diagnose and the right to perform } \\
\text { psychotherapy nearly every time it is in the proposed legislation. They seem to } \\
\text { think these services are their domain. [H3 (N)] }\end{array}$ \\
\hline
\end{tabular}




\begin{tabular}{l|l|l}
\hline Theme & Code & Supporting Responses \\
\hline Incidental events [H11] & $\begin{array}{l}\text { Brothers who were both in influential political positions took opposite } \\
\text { positions on the social work bill. For whatever reason, the bill triggered } \\
\text { competitiveness and their disagreements spread vastly causing nearly polar } \\
\text { divides causing a very close vote. [H11 (MN)] }\end{array}$ \\
\hline
\end{tabular}

Notes: *A code, for example H1, identifies the historian from which the theme was initially identified. The initial comment from the historian supporting the theme is listed above. $* * \mathrm{~N}=$ National historian

\section{Solutions}

Historians were asked to identify solutions used in overcoming barriers in their attempts to pass or change legislation that regulates clinical social work licensing. Historians offered a list of 22 solution themes. Their solution-related themes were then grouped using restricted coding by the project team into three groups to facilitate theory development. Table 2 provides a summary of the themes emerging from the interviews along with examples of supporting responses. Some responses are summarized for brevity while others are direct quotes.

Table 2. Solutions Used in Passing Social Work-Related Legislation

\begin{tabular}{|c|c|c|}
\hline Theme & Code & Supporting Responses \\
\hline \multirow{8}{*}{$\begin{array}{l}\text { Intra } \\
\text { Professional } \\
\text { (Within Social } \\
\text { Work) }\end{array}$} & $\begin{array}{l}\text { Get the "players" on the } \\
\text { same page (have a } \\
\text { unified goal) }[\mathrm{H} 3 *]\end{array}$ & $\begin{array}{l}\text { Get everyone interested in the project on the same page before attempting to } \\
\text { move the bill forward. }\left[\mathrm{H} 3\left(\mathrm{~N}^{* *}\right)\right]\end{array}$ \\
\hline & $\begin{array}{l}\text { Prepare - Legislative } \\
\text { work takes time and } \\
\text { money }[\mathrm{H} 3]\end{array}$ & $\begin{array}{l}\text { Social workers often get passionate about an issue, like not being able to } \\
\text { diagnose. They want to jump in and make things right. The groundwork has to } \\
\text { be laid for it to happen, and it takes lots of time and money to be ready. [H3 } \\
\text { (N)] }\end{array}$ \\
\hline & $\begin{array}{l}\text { Get social workers to } \\
\text { engage [H2] Get social } \\
\text { workers involved [H1] }\end{array}$ & $\begin{array}{l}\text { Make sure social workers understand the issues/needs to pass legislation and } \\
\text { make sure they are not passive about the issues. Get social workers to speak to } \\
\text { legislators about importance of the bill and on the economic benefits. [H1 } \\
\text { (TX)] }\end{array}$ \\
\hline & $\begin{array}{l}\text { Importance of writing } \\
\text { good social work } \\
\text { legislative proposals } \\
\text { (Simplify the laws) [H5] }\end{array}$ & $\begin{array}{l}\text { Social work laws have become too specialized, which creates confusion and } \\
\text { diminishes the ability to promote a national platform. Focus on making laws } \\
\text { simpler and defining specializations in the rules. Use ASWB's Model Social } \\
\text { Work Practice Act as a model for simple laws. [H5 (N**)] }\end{array}$ \\
\hline & $\begin{array}{l}\text { Importance of writing } \\
\text { good social work } \\
\text { legislative proposals } \\
\text { (Get the right content in } \\
\text { the laws) [H5] }\end{array}$ & $\begin{array}{l}\text { For clinical social work laws, make sure to include the right to diagnose and } \\
\text { the right to perform psychotherapy in the law. Address the proper level of } \\
\text { ASWB exam necessary for safe practice in relation to the scope of practice. For } \\
\text { example, clinical social work licensure needs to require the clinical level of } \\
\text { exam. [H3 (N)] }\end{array}$ \\
\hline & $\begin{array}{l}\text { Support candidates who } \\
\text { share social work values } \\
{[\mathrm{H} 2]}\end{array}$ & $\begin{array}{l}\text { Support candidates who share social work values. Candidates who were } \\
\text { endorsed and who win become legislative champions. [H } 2 \text { (TX)] }\end{array}$ \\
\hline & $\begin{array}{l}\text { Get all social workers } \\
\text { licensed [H5] }\end{array}$ & $\begin{array}{l}\text { Having states that do not regulate categories of social work practice and having } \\
\text { social workers who practice unlicensed devalues the profession and protection } \\
\text { of the public. [H5 (N)] }\end{array}$ \\
\hline & $\begin{array}{l}\text { Work out professional } \\
\text { problems within the } \\
\text { profession, not in the } \\
\text { legislature [H9] }\end{array}$ & $\begin{array}{l}\text { Take problems to the professional organizations for resolve. It does not look } \\
\text { good for the profession to air dirty laundry in the legislature. It's more harmful } \\
\text { than people know. [H9 (TX)] }\end{array}$ \\
\hline
\end{tabular}




\begin{tabular}{|c|c|c|}
\hline Theme & Code & Supporting Responses \\
\hline & $\begin{array}{l}\text { Protect the discipline, } \\
\text { just like other } \\
\text { disciplines do [H8] }\end{array}$ & $\begin{array}{l}\text { Social work must stay alert when other disciplines propose legislation and speak } \\
\text { up, either in support or opposition. Social work has to be invested in protecting } \\
\text { our domain just as other professions do. [H8 (FL)] }\end{array}$ \\
\hline \multirow{6}{*}{$\begin{array}{l}\text { Inter } \\
\text { Professional } \\
\text { (with Other } \\
\text { Professions) }\end{array}$} & $\begin{array}{l}\text { Relationships (With } \\
\text { Legislators) [H1] }\end{array}$ & $\begin{array}{l}\text { Spend a lot of time in the state house and never let a week pass without talking } \\
\text { to legislators. Know individual legislators well on both sides of the aisle. [H1 } \\
\text { (TX)] }\end{array}$ \\
\hline & $\begin{array}{l}\text { Relationships (Develop } \\
\text { Coalitions and } \\
\text { Committees) }[\mathrm{H} 1]\end{array}$ & $\begin{array}{l}\text { NASW has lobbyists and a political action committee to help bills get on } \\
\text { calendars and into committees. [H2 (TX)] }\end{array}$ \\
\hline & $\begin{array}{l}\text { Relationships } \\
\text { (Networking) [H1] }\end{array}$ & $\begin{array}{l}\text { Know people who know people who are good spokespersons for what social } \\
\text { workers did for them. Use them to testify in hearings, write letters, and to } \\
\text { generally communicate with legislators. [H1 (TX)] }\end{array}$ \\
\hline & $\begin{array}{l}\text { Relationships (Find and } \\
\text { work with allies) [H1] }\end{array}$ & $\begin{array}{l}\text { We found } 2 \text { sponsors that believed in social work who were willing to help us. } \\
\text { It was extremely beneficial to have a state level Society for Clinical Social } \\
\text { Work. They advocate for clinical when other associations will not. [H6 (TX)] }\end{array}$ \\
\hline & $\begin{array}{l}\text { Relationships (Know } \\
\text { the opposition) [H1] }\end{array}$ & Use relationships to know the issues and know the opposition. [H8 (FL)] \\
\hline & Involve the public [H2] & $\begin{array}{l}\text { Inform people through public service campaigns. Solicit the public to speak to } \\
\text { legislators and share their opinions and concerns. [H2 (TX)] }\end{array}$ \\
\hline \multirow[t]{10}{*}{$\begin{array}{l}\text { Broader } \\
\text { Perspective }\end{array}$} & Educate [H1] & $\begin{array}{l}\text { Share information through brochures and pamphlets to legislators and the } \\
\text { public. Information helps individual legislators get on the same page; it helps } \\
\text { them understand the issues and problems and overcome myths and stigmas. } \\
\text { [H1 (TX)] }\end{array}$ \\
\hline & Make the cause real $[\mathrm{H} 1]$ & $\begin{array}{l}\text { Use stories that reach legislators and sprinkle in statistics, not vice versa. } \\
\text { Address depth of impact and use emotional appeal. Always include money and } \\
\text { statistics, and phrase the proposal in a way that supports a low budget request. } \\
\text { [H1 (TX)] }\end{array}$ \\
\hline & Work the Process [H2] & $\begin{array}{l}\text { As soon as issues arise that appear to be coming into a need for legislation } \\
\text { change, start working the process. Start talking with "legislative champions } \\
\text { and partners" to get them on board and informed. [H } 2 \text { (TX)] }\end{array}$ \\
\hline & Reframe issues [H2] & $\begin{array}{l}\text { Use language that the legislators understand; do not force one's agenda. The } \\
\text { most direct route may be too direct. Examples: Underfunded Medicaid vs } \\
\text { workforce needs; Practice act vs title protection. [H2 (TX)] }\end{array}$ \\
\hline & Use a narrow focus $[\mathrm{H} 2]$ & $\begin{array}{l}\text { "You can't do everything about everything, but you can pick one or two things } \\
\text { and make a difference." [H2 (TX)] }\end{array}$ \\
\hline & $\begin{array}{l}\text { Prepare a strong defense } \\
\text { to points of opposition } \\
\text { [H8] }\end{array}$ & $\begin{array}{l}\text { Once social workers know the opposition to the proposed legislation, it is } \\
\text { essential to prepare a strong defense to present when the bill is heard. [H8 } \\
\text { (FL)] }\end{array}$ \\
\hline & $\begin{array}{l}\text { Know the political } \\
\text { environment and the } \\
\text { "hot topics" [H3] }\end{array}$ & $\begin{array}{l}\text { Back in the } 1990 \text { s when much of the legislative work for social work } \\
\text { regulation took place, the political climate was much friendlier to regulation } \\
\text { than it is today. }[\mathrm{H} 3(\mathrm{~N})]\end{array}$ \\
\hline & Timing [H6] & $\begin{array}{l}\text { A lawsuit exposed inadequacies of certification; it brought to light the need for } \\
\text { licensure instead of certification. [H6 (TX)] }\end{array}$ \\
\hline & Use technology [H6] & $\begin{array}{l}\text { Use technology to facilitate solutions via research, communication, and } \\
\text { problem solving. [H6 (TX)] }\end{array}$ \\
\hline & $\begin{array}{l}\text { Compromise/Negotiate } \\
\text { [H6] }\end{array}$ & $\begin{array}{l}\text { Texas will never pass a practice act. OK, work with what they will accept. The } \\
\text { social workers did not get exactly what was wanted, but did get a start toward } \\
\text { regulation. The board used the rules to make further adjustments to address } \\
\text { what the law did not. [H6 (TX)] }\end{array}$ \\
\hline
\end{tabular}




\begin{tabular}{|c|c|c|}
\hline Theme & Code & Supporting Responses \\
\hline & $\begin{array}{l}\text { Persistence and } \\
\text { dedication [H6] }\end{array}$ & $\begin{array}{l}\text { "We worked like dogs, drew in everyone we knew, and drove the legislature } \\
\text { crazy. We were not willing to give up." [H6 (TX)] }\end{array}$ \\
\hline & $\begin{array}{l}\text { Be prepared to react } \\
\text { quickly when legislature } \\
\text { is in session [H11] }\end{array}$ & $\begin{array}{l}\text { Time was running out on the last day of session and it was looking like the } \\
\text { agenda was not going to reach the social work related bill. The sponsor } \\
\text { interrupted the Speaker and asked for a modification of the agenda, the bill was } \\
\text { heard just before the session closed. The bill passed. Had this not happened, it } \\
\text { likely would not have passed even during the next annual session. [H11 (MN)] }\end{array}$ \\
\hline
\end{tabular}

\section{Discussion and Emerging Theory}

Achieving success in passing legislation that regulates clinical social work licensing is a complex and multifaceted endeavor. There are significant potential barriers complicating a seemingly straightforward process. As with the discipline itself, the problems occur at the micro, mezzo, and macro levels and are so complex and intertwined that they are nearly undefinable. This study successfully identified some of the potential barriers, but perhaps more importantly, it has produced a strategic method for approaching policy proposals and passing social work related legislation. Each of the emergent themes was somewhat simplistic, but when grouped via restricted coding into a systematic strategy, the themes reveal that social work related legislation is achievable. Figure 1 provides a visual demonstration to aid in understanding how this systems approach works.

This emerging theory requires understanding and synthesis of the study's results. Each of the Barrier or Solution themes, alone, essentially has little meaning. The Barriers and Solutions are interrelated, but not in a one-to-one linear manner. There is never only one barrier to passing legislation. If this were true, the solution would likely not require a systemic strategy. Achieving policy change requires thinking in terms of systems and synthesis, knowing the environment, and making predictions using critical thinking and problem-solving strategies. As an example, legislators having misinformed perspectives is a complex barrier. The team proposing legislative change needs to understand political climate, historic processes previously used in legislative change, use relationships to be well-informed about specific barriers and who the players are, and know the resistance likely to present with the proposed legislation. Given the complexity of barriers, and recognizing in many cases there are multiple barriers, it becomes important to recognize and develop a strategy (i.e. a strategic plan) involving multiple Solution themes as a critical part of seeking legislative change. Strategy helps assure systems issues are addressed from the beginning when early coordinated efforts begin, through the working phase when outreach and education occur, and through final phases when the proposed policy comes to the legislative floor. Solution themes which may address the barriers vary by jurisdiction, but might include education, using relationships in multiple ways, preparing strong evidence to defend against opposition, and using real stories to add impact to the issue. 
Figure 1. The Legislative Change Systems Theory

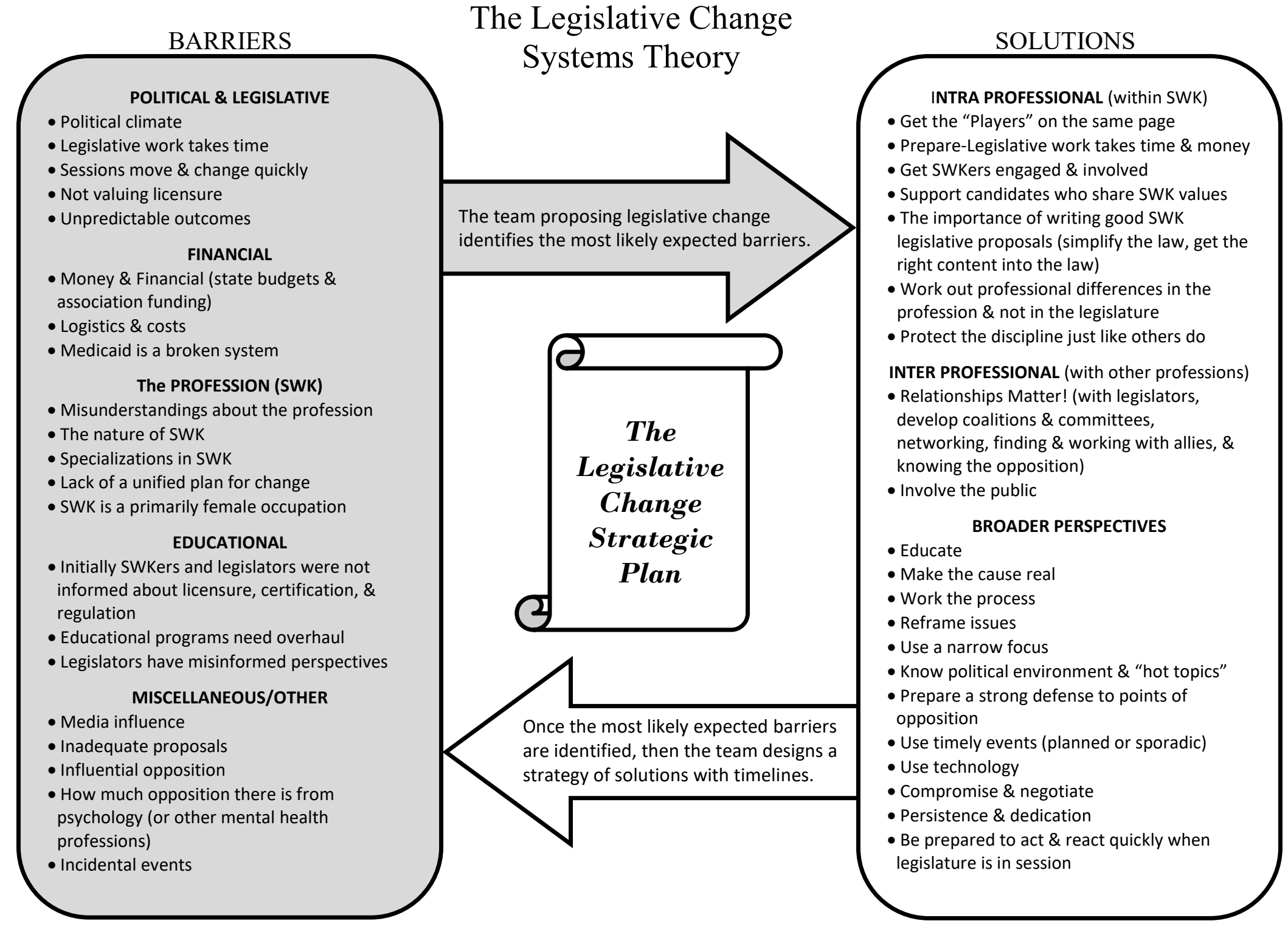


The solutions identified by historians did not directly align with the barriers identified by the historians. The semi-structured interview format was not designed in a manner that would ensure alignment. The researcher recognized jurisdictions may have encountered barriers for which a solution was not clear, or perhaps there were several solutions which did not perfectly align with an identified barrier. The intent, from the onset of the study, was to ask broad and open questions promoting depth of thought about the issues and needs in changing social work related regulation. The identified barrier themes were broad enough to encompass several specific examples, yet specific enough to be understood and categorized. The solutions themes followed this same pattern.

Other themes may apply based on unique circumstances within any jurisdiction. As stated previously, it is assumed the barrier themes identified in this study offer valuable consideration to multiple jurisdictions that intend to address social work related legislative change, and the solution themes identified in the study offer valuable consideration in designing effective strategies to overcome the barriers. Furthermore, this emerging theory may be useful in addressing changes to broader social work-related policies since many of the barriers and solutions identified in the study do not directly align only with clinical social work.

\section{Limitations}

The first, and perhaps most obvious, limitation in the study was the small sample size of 12 historians from three states. A second limitation of the study was lack of representation from western and small states. These limitations were somewhat mitigated by having some historians who spoke to both barriers and solutions based on their experience in working with more than 25 jurisdictions. The sample of historians was professionally homogeneous; all but one of the historians identified as social workers and the $12^{\text {th }}$ was licensed as a social worker under the grandfathering clause. Although the study was designed to accept non-social work historians, snowball sampling did not lead to inclusion of politicians, governors, or individuals from other disciplines. Having primary social workers as historians precludes the obviously valuable perspectives of the broader range of professionals involved in the legislative process. Lastly, ethnicity of the historians was not collected within the study.

\section{Impact and Significance of Study}

The knowledge acquired from this study was used to create an emerging theory based on a framework to strategically address the barriers experienced in three states during the process of changing legislation to allow licensed clinical social workers to provide private and independent mental health services. The emerging theory produced a framework constructed of the solutions used in the same three states to successfully achieve clinical social work legislation.

One benefit of this study is its potential support for ASWB's mission to achieve practice mobility and license portability of social work practice. Licensed clinical social work continues to have some inconsistencies in scope of practice. Social workers, including licensed clinical social workers, may want to seek changes to facilitate scope of 
practice that aligns with the ASWB Model Social Work Practice Act (ASWB, 2015b). The purpose of the emerging theory's framework is to help social workers achieve legislative change, thus facilitating a more legally aligned, standardized scope of practice of licensed clinical social work across the United States. In doing so, the public, the profession, and other invested parties have a better understanding of the social work profession. Having a more commonly understood scope of practice (i.e. licensed clinical social workers being able to provide private and independent mental health services nationwide) helps to fulfill the mission of licensure (i.e. to protect the public and the profession) in addition to facilitating ASWB's goal (i.e. to achieve practice mobility and license portability for social workers). Although this emerging theory can serve many purposes involving social work related policy change, the most obvious, somewhat immediate, use includes facilitation of change in the states that do not have regulation in place for licensed clinical social workers to diagnose, as well as the states who do not have regulation in place for licensed clinical social workers to practice psychotherapy.

\section{Conclusions}

Social workers do not define social work practice; scope of practice is defined in regulations at the jurisdictional level. As such, the policies impacting licensed clinical social workers and their ability to perform private and independent mental health services vary among the jurisdictions of the United States (Cooper-Bolinskey, 2017; Groshong, 2009). While states are making progress toward establishing a standard allowing for national reciprocity, there remain jurisdictions with significant variations in laws regulating clinical social work practice. These variations impact social work service delivery, accessibility to services by those in need of mental health services, and portability of social work licenses used to provide mental health services. The aforementioned emerging theory provides a resource to clinical social workers in need of guidance for changing social work related legislation. The resulting knowledge may well impact the resources, processes, or strategies used to facilitate change regulating social work practice.

The public is better protected when clients have a good understanding of safe professional social work practice (Marks \& Knox, 2015). The profession is better protected when scope of practice is at least somewhat comparable across jurisdictions (though jurisdiction-specific needs can be accommodated beyond common foundational practices; ASWB, 2015b; Cooper-Bolinskey, 2017; Groshong, 2009). Portability of services is more achievable when there is a universally recognized legal standard of clinical social work practice (ASWB, 2017; Groshong, 2009). Finally, a more universally recognized legal standard of clinical social work practice removes many unnecessary restrictions on wellqualified mental health providers, making more providers available to serve those in need of mental health services (Cooper-Bolinskey \& Blower, 2016; Groshong, 2009).

\section{References}

Association of Social Work Boards [ASWB]. (2015a). Total number of social workers

(October 1, 2015 Data File). Culpeper, VA: Author.

ASWB. (2015b). Model Social Work Practice Act. Culpepper, VA: Author. 
ASWB. (2016). Services. Retrieved from http://members.aswb.org/services/

ASWB. (2017). Social work practice mobility. Retrieved from http://movingsocialwork.org/

ASWB. (2018a). Compare license information. Retrieved from http://aswbsocialworkregulations.org/licenseReportBuilder.jsp

ASWB. (2018b). Number of jurisdictions in each license category (September 24, 2018 Data File). Culpeper, VA: Author.

ASWB. (2018c). Total number of social workers (September 28, 2018 Data File). Culpeper, VA: Author.

ASWB. (2019). Social work practice mobility. Retrieved from www.movingsocialwork.org

Bibus, A., \& Boutte-Queen, N. (2011). Regulating social work: A primer on licensing practice. Chicago, IL: Lyceum Books, Inc.

Biggerstaff, M. A. (1995). Licensing, regulation, and certification. In R. L. Edwards \& J. G. Hopps (Eds.), Encyclopedia of social work. Washington, DC: NASW Press.

Clark, E. J. (2013). National Association of Social Workers. In T. Mizrahi et al. (Eds.), Encyclopedia of social work. Washington, DC: NASW Press and New York, NY: Oxford University Press. doi: https://doi.org/10.1093/acrefore/9780199975839.013.260

Collins, D., Coleman, H., \& Miller, P. (2002). Regulation of social work: A confusing landscape. Canadian Social Work Review, 19(2), 205-225.

Cooper-Bolinskey, D. (2017). Identifying problems and solutions in changing state legislation regarding licensed clinical social workers providing private independent mental health services (Doctoral dissertation). Retrieved from ProQuest Dissertations $\&$ Theses Global (order number 10693691).

Cooper-Bolinskey, D., \& Blower, C. (2016). Pursuing legislative authority for clinical social workers to provide private independent mental health services in the United States: What is the status and what are the issues? Journal of Sociology and Social Work, 4(1), 26-34. doi: https://doi.org/10.15640/jssw.v4n1a4

Corbin, J., \& Strauss, A. (2015). Basics of qualitative research: Techniques and procedures for developing grounded theory (4th ed.). Thousand Oaks, CA: Sage.

Council on Social Work Education. (2018). Curricular guide for licensing and regulation: 2015 EPAS curricular guide resource series. Alexandria, VA: Council on Social Work Education.

Dyeson, T. (2004). Social work licensure: A brief history and description. Home Health Care Management \& Practice, 16, 408-411. doi: https://doi.org/10.1177/1084822304264657 
Epple, D. (2007). Inter and intra professional social work differences: Social work's challenge. Clinical Social Work Journal, 35(4), 267-276. doi: https://doi.org/10.1007/s10615-007-0098-0

Groshong, L. (2009). Clinical social work practice and regulation: An overview. Lanham, MD: University Press of America, Inc.

Marks, A. T., \& Knox, K. S. (2015). Social work regulation and licensing. In K. Corcoran \& A. R. Roberts (Eds.), Social workers' desk reference (3rd ed.). New York, NY: Oxford University Press.

McNutt, J. G. (2013). Social work practice: History and evolution. In T. Mizrahi et al. (Eds.), Encyclopedia of social work. Washington, DC: NASW Press and New York, NY: Oxford University Press. doi: https://doi.org/10.1093/acrefore/9780199975839.013.620

National Association of Social Workers. (2016). Mental health. Retrieved from http://www.naswdc.org/pressroom/features/issue/mental.asp

NVivo. (2017). NVivo Pro 11 for Windows. Retrieved from http://www.qsrinternational.com/nvivo/nvivo-products/nvivo-11-for-windows/nvivopro

Randall, A. D., \& DeAngelis, D. (2013). Licensing. In T. Mizrahi et al. (Eds.), Encyclopedia of social work. Washington, DC: NASW Press and New York, NY: Oxford University Press. doi: https://doi.org/10.1093/acrefore/9780199975839.013.225

Stuart, P. H. (2013). Social work profession: History. In T. Mizrahi et al. (Eds.), Encyclopedia of social work. Washington, DC: NASW Press and New York, NY: Oxford University Press. doi: https://doi.org/10.1093/acrefore/9780199975839.013.623

U.S. Centers for Medicare and Medicaid Services. (2018). National provider identifier registry file from December 11, 2018 [downloadable]. Retrieved from http://download.cms.gov/nppes/NPI_Files.html

Weismiller, T., \& Whitaker, T. (2013). Social work profession: Workforce. In T. Mizrahi et al. (Eds.), Encyclopedia of social work. Washington, DC: NASW Press and New York, NY: Oxford University Press. doi: https://doi.org/10.1093/acrefore/9780199975839.013.624

Author note: Address correspondence to: Dianna Cooper-Bolinskey, 30 Allendale, Terre Haute, IN 47802. E-mail: dirucobo@hotmail.com 